renal clearance of uric acid. At this concentration $(22 \mathrm{mg} /$ $100 \mathrm{ml}$ ) of uric acid there would be a significant risk of further renal damage due to precipitation of uric acid crystals within the renal tubules.

This case emphasizes the severity of the systemic disorders which may be associated with skin disease.

Requests for reprints should be addressed to Dr. D. J. Warren at the Medical Renal Unit, Royal Infirmary, Edinburgh EH3 9YW.

\section{References}

Baker, H., and Ryan, T. J. (1968). British fournal of Dermatology, 80, 711 ,
Bauer, F. (1953). Australian fournal of Dermatology, 2, 69.

Braverman, I. M. Cohen, I. and O'Keefe, E. (1972) Archives of Dermatology, 105, 189 .

Butterworth, T. (1936). Archives of Dermatology and Syphology, 34, 676.

Copeman, P. W. M., and Bold, A. M. (1965). Proceedings of the Royal Society of Medicine, $\mathbf{5 8}, \mathbf{4 2 5}$

Eisen, A. Z., and Seegmiller, J. E. (1961). Journal of Clinical Investigation 40,1486 .

Kaplan, H., and Klatskin, G. (1960). Yale Fournal of Biology and Medicine, $32,335$.

Marks, J., and Shuster, S. (1966). British Medical fournal, 2, 88.

Pegum, J. S. (1951). Guy's Hospital Reports, 100, 304

Shelley, W. B (1967) Fournal of the American Medical Association, 201, 1009. Butterworths.

Shustemic Effects of Skin Disease. London, Heineman Medical Books.

Shuster, S., and Wilkinson, P. (1963). British fournal of Dermatology, 75, 344

Shuster, S., and Wilkinson, P. (1963). British fournal of Dermatology, 75, 344.
Tickner, A., and Basit, A. (1960). British fournal of Dermatology, 72, 138.

\title{
Thyrotoxicosis and Giant-Cell Arteritis
}

\author{
R. D. THOMAS, D. N. CROFT
}

British Medical fournal, 1974, 2, 408-409

\section{Summary}

In a retrospective survey we found that five (8.5\%) out of 59 women with giant-cell arteritis had a history of thyrotoxicosis. This was significantly higher than in a control group of patients. Giant-cell arteritis and thyrotoxicosis occurred simultaneously in two cases. Knowledge of this association is of clinical use and is further evidence for an immunological basis for giant-cell arteritis.

\section{Introduction}

We have recently seen three patients with giant-cell arteritis, of whom one had thyrotoxicosis and two had primary hypothyroidism. This was of interest as a clinical observation and in relation to the aetiology of these disorders. We therefore carried out a retrospective survey to determine whether there was an association between thyroid dysfunction and giant-cell arteritis.

\section{Patients and Methods}

The notes of all patients with giant-cell arteritis who attended the hospital from 1957 to 1972 were examined for a history of thyrotoxicosis and primary hypothyroidism. These diagnoses were accepted when confirmed by radioiodine uptake and measurement of blood thyroidal hormones.

There were 101 cases of giant cell arteritis. In 58 of them the diagnosis had been confirmed by a temporal artery biopsy. In 19 of the remaining 43 no biopsy had been performed because there was no doubt of the diagnosis and in 24 the biopsy findings were negative. All of the 43 patients in whom the diagnosis had not been confirmed by biopsy had a typical history (Hamilton et al., 1971), a raised erythrocyte sedimentation rate, and had responded well to treatment with systemic corticosteroids. It is well known that the temporal artery may appear normal in a single biopsy examination in patients with

giant-cell arteritis (Birkhead et al., 1957), so we had little hesitation in including in our study the patients in whom the biopsy findings had been negative. We have called the patients with biopsy evidence of giant-cell arteritis the "confirmed" group, and those without biopsy evidence the "clinical" group. There were 32 women and 26 men in the confirmed group and 27 women and 16 men in the clinical group. The differences in age and erythrocyte sedimentation rate between the two groups of patients were not significant, and the mean age of all patients was 70.3 years.

Because there were no cases of thyroid dysfunction among the men studied we excluded men from the control group. This comprised 200 women aged 50 years or more (mean age 70.6 years) who had been consecutive acute admissions to hospital with pneumonia. The prevalence of thyrotoxicosis and hypothyroidism among them was assessed by the same criteria as in the patients with giant-cell arteritis.

\section{Results}

A history of thyrotoxicosis was found in three out of 32 women with confirmed giant-cell arteritis and in two out of the 27 women with clinical giant-cell arteritis-an overall prevalence $8.5 \%$. There were two $(3.4 \%)$ cases of hypothyroidism, both in women. There were no cases of thyrotoxicosis or hypothyroidism in men. Among the 200 controls there were three cases of thyrotoxicosis and four of hypothyroidism-a prevalence of $1.5 \%$ and $2 \%$ respectively.

Therefore in women with giant-cell arteritis the prevalence of thyrotoxicosis was $8.5 \%$ compared with $1.5 \%$ in the control group. The difference was significant $(\mathrm{P}<0.017)$. Because of the small numbers Fisher's exact test for comparing two proportions in a $2 \times 2$ table was used for the analysis. There was no significant difference in the prevalence of hypothyroidism. If we discount the case that drew our attention to the association the prevalence becomes $6.8 \%$, which is also significant $(P<0.05)$.

Arteritis followed thyrotoxicosis at intervals of four and a half, six, and 15 years respectively in three cases, and in two the diseases occurred simultaneously. These two, described below, are of particular interest.

Case 1.-A 74-year-old woman presented with a two-year history of episodic muscular weakness and tremor associated with temporal and occipital headaches, scalp tenderness, and blurred vision. She appeared thyrotoxic and had a score of 21 on the Wayne Clinical Index (Crooks et al., 1959). The temporal arteries 
were clinically normal. Two days later she lost the vision in the lower half of the right visual field and the right optic disc was swollen. Haemoglobin was $81 \%$; erythrocyte sedimentation rate 60, I $\mathrm{I}^{131}$ uptake $84 \cdot 6 \%$ at 24 hours, and $\mathrm{T}-4$ dialysate $1 \cdot 12 \%$ (normal $0 \cdot 46-0 \cdot 80 \%$ ). Biopsy of the temporal artery showed giantcoll arteritis. She responded to treatment with prednisone and radioiodine.

Case 2.-A 62-year-old woman developed painful temporal

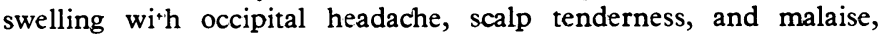
which subsided in a month. One month later she suffered weight loss, intolerance of heat, sweating, and diarrhoea. She was clinically thyrotoxic with a score of 20 on the Wayne Clinical Index. The temporal arteries were clinically normal. On investigation protein bound iodine was $19.6 \mu \mathrm{g} / 100 \mathrm{ml}$ (normal 4-8 $\mu \mathrm{g} / 100 \mathrm{ml}$ ) and the erythrocyte sedimentation rate 123 . Temporal artery biopsy confirmed the diagnosis of giant-cell arteritis and treatment with prednisone $40 \mathrm{mg} /$ day was started. Six days later the $I^{131}$ uptake was $26 \%$ at four hours, the P.B.I. $8.3 \mu \mathrm{g} / 100 \mathrm{ml}$, and the T-3 binding coefficient $256 \%$ (normal $92-120 \%$ ). Thyroid antibodies were not present. Though this indicated hyperthyroidism no additional therapy was given. Five weeks later she appeared euthvroid, with a Wayne Clinical Index score of 8, P.B.I. 50 $\mu \mathrm{g} / 100 \mathrm{ml}$, and $\mathrm{T}-3$ binding coefficient $106 \%$. We concluded that she had a spontaneous remission of thyrotoxicosis or that it was suppressed by corticosteroid treatment (Werner and Platman, 1965).

\section{Discussion}

Many large series of cases of giant-cell arteritis have been reported but in most there is no mention of associated diseases (Hamilton et al., 1971). In a report of cases from the Mayo Clinic (Hauser et al., 1971), however, four of the 19 patients had previously had a thyroidectomy for goitre but there is no mention of thyroid dysfunction. There is a close link between giant-cell arteritis and polymyalgia rheumatica, and in a study of 94 cases of these diseases Fauchald et al. (1972) claimed that there was no clear difference between them. They also reported a case of a woman who presented with a simultaneous onset of hypothyroidism and polymyalgia rheumatica. Niarchos and Finn (1973) reported an association between hypothyroidism and abdominal aneurysm and suggested that the arterial disease was due to an immunological disorder affecting the aorta.

An association of two diseases, particularly with a simultaneous onset, may indicate a common cause. The evidence for an autoimmune basis for thyrotoxicosis is considerable (Werner et al., 1972) and it has been associated with many other diseases thought to be autoimmune. Giant-cell arteritis is also considered to be a disease of altered immunity (Sandok, 1972). That it should be associated with thyrotoxicosis is therefore not entirely unexpected. This association has clinical relevance and adds to other indirect evidence that giantcell arteritis is caused or perpetuated by an abnormal immune mechanism.

We thank Dr. B. Creamer for allowing us to report clinical details of two patients and Mr. A. Swan for statistical help.

\section{References}

Birkhead, N. C., Wagener, H. P., and Shick, R. M. (1957). Fournal of the American Medical Association, 163, 821.

Crooks, J., Murray, I. P. C., and Wayne, E. J. (1959). Quarterly fournal of Medicine, 28, 211.

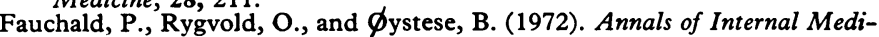
cine, $77,845$.

Hamilton, C. R., Shelley, W. M., and Tumulty, P. A. (1971). Medicine,

50, 1 W. A., Ferguson, R. H., Holley, K. E., and Kurland, L. T. (1971). Mayo Clinic Proceedings, 46, 597

Niarchos, A. P., and Finn, R. (1973). British Medical Fournal, 4, 110.

Sandok, B. A. (1972). Fournal of the American Medical Association, 222, 1405. Sandok, B. A. (1972), Fournal of the American Medical Associat

Werner, S. C., Wegelius, O., Fierer, J. A., and Hsu, K. C. (1972). Nerv England fournal of Medicine, 287, 421 .

\title{
Alpha-chain Disease with Clinical, Immunological, and Histological Recovery
}

\author{
O. N. MANOUSOS, J. C. ECONOMIDOU, D. E. GEORGIADOU, \\ K. G. PRATSIKA-OUGOURLOGLOU, S. J. HADZIYANNIS, \\ G. E. MERIKAS, K. HENRY, W. F. DOE
}

British Medical fournal, 1974, 2, 409-412

\section{Summary}

Clinical, immunological, and histological recovery in a patient with alpha-chain disease is described. The patient, a 27-yearold Greek man, presented with severe steatorrhoea, abdominal pain, oedema, and hypogammaglobulinaemia. Treat-

Second Medical Department of Athens University Medical School, Hippokration General Hospital, Athens, Greece

O. N. MANOUSOS, M.D., PH.D., Assistant Prcfessor of Medicine J. C. ECONOMIDOU, M. D., PH.D., Assistant Professor of Medicine J. C. ECONOMINOU, M. D., PH.D., Assistant Professor of Med

G. E. MERIKAS, M. D., Professor of Medicine

University of Athens, Athens, Greece

D. E. GEORGIADOU, M.D., Assistant Professor of Pathology

Department of Pathology, Hippokration General Hospital, Athens, Greece

K. G. PRATSIKA-OUGOURLOGLOU, M.D., Head of Department

Royal Postgraduate Medical School, Hammersmith Hospital, London W12 0HS

K. HENRY, M.R.C.P., Lecturer in Histopathology

W. F. DOE, M.SC., M.R.C.P., Lecturer in Medicine ment with tetracycline produced only temporary remission. Intermittent therapy with prednisone and cyclophosphamide together with antibiotics was followed by clinical recovery, return of histological appearances of the small intestine to normal, and disappearance of free alpha-chain protein from the serum. The patient remained well one year later without treatment.

\section{Introduction}

Alpha-chain disease was first described by Seligmann et al. (1968). They reported the presence of a heavy chain fragment of $\operatorname{IgA}$, free of light chains, in the serum, urine, and jejunal fluid of a patient suffering from so-called "Mediterranean lymphoma," a disease now known to occur in populations of diverse geographic and ethnic origins (Seligmann et al., 1971; Novis et al., 1971; Doe et al., 1972). Alpha-chain disease affects young patients and is characterized clinically by diarrhoea, abdominal pain, and finger clubbing. Histologically there is diffuse, predominantly plasma cell, infiltration of the wall of the small intestine.

Little is known about natural history and response to therapy in this condition. While remission has been achieved 